\title{
Sosialisasi Perpajakan Pada Pelaku Usaha UMKM di Kota Cimahi
}

\author{
Rizki Indrawan*1, Annisa Yuniar Larasati ${ }^{2}$, Purwanto $^{3}$, Usman Sastradipraja ${ }^{4}$, Sofia Windarti ${ }^{5}$ \\ 1,2,3,4,5Program Studi Akuntansi, Fakultas Ekonomi dan Bisnis, Universitas Jenderal Achmad Yani \\ *e-mail: rizki.indrawan@lecture.unjani.ac.id ${ }^{1}$
}

\begin{abstract}
Community service activities are carried out on MSMEs assisted by the Cimahi city government, West Java. This activity is in the form of socializing the role of MSMEs in taxation and incentives for those affected by COVID-19. The goal is for MSMEs to understand their tax obligations, namely calculating, depositing and reporting taxes and taking advantage of tax incentives provided by the government for business actors affected by the COVID-19 pandemic. Incentives given to MSME actors by reducing the PPh rate (Final Income Tax) to $0.5 \%$ of total turnover, according to Government Regulation (PP) Number 23 of 2018 concerning Income Tax on income from businesses received or obtained by Taxpayers who have gross income certain. turnover. Then briefing on the extension of incentives due to this pandemic by utilizing the tax payment abolition facility with the DTP PPh Final mechanism as stated in PMK-82/PMK.03/2021. The implementation is carried out using a webinar mechanism in August 2021. The initial agenda for this activity is coordinated by the activity committee through the WhatsApp group by distributing flyers with the intention that the socialization activities carried out can be followed by the fostered MSME business actors. by the City Government of Cimahi. The output of this activity is to make MSME actors aware of their tax obligations for the business they run, understand how to utilize and use DTP Final Income Tax incentives and calculate, deposit and report taxes.
\end{abstract}

Keywords: MSMEs, incentives, tax socialization

\begin{abstract}
Abstrak
Kegiatan pengabdian masyarakat dilakukan pada UMKM Binaan pemerintah kota Cimahi, Jawa Barat. Kegiatan ini berupa sosialisasi peran UMKM pada perpajakan dan insentif bagi yang terdampak covid19. Tujuannya adalah agar UMKM memahami kewajiban perpajakannya yaitu memperhitungkan, menyetor dan pelaporan pajak serta memanfaatkan insentif pajak yang diberikan oleh pemerintah bagi pelaku usaha terdampak pandemi covid-19. Insentif yang diberikan kepada pelaku UMKM dengan menurunkan tarif PPh (PPh Final) menjadi 0,5\% dari total omzet, sesuai Peraturan Pemerintah (PP) No 23 Tahun 2018 tentang PPh atas penghasilan dari usaha yang diterima atau diperoleh wajib pajak yang memiliki peredaran bruto tertentu. Kemudian pengarahan mengenai perpanjangan insentif akibat pandemi ini dengan memanfaatkan fasilitas penghapusan pembayaran pajak dengan mekanisme PPh Final DTP yang tertuang dalam PMK82/PMK.03/2021. Pelaksanaan dilakukan dengan menggunakan mekanisme webinar pada bulan Agustus 2021. Agenda awal kegiatan ini adalah melakukan koordinasi oleh panitia kegiatan melalui grup WhatsApp dengan penyebaran flyer dengan maksud agar kegiatan sosialisasi yang dilaksanakan ini dapat dihadiri oleh pelaku usaha UMKM binaan pemerintah kota Cimahi. Output kegiatan ini menjadikan pelaku UMKM sadar mengenai kewajiban pajak atas usaha yang dijalankan, paham dalam memanfaatkan dan menggunakan insentif PPh Final DTP serta menghitung, menyetor dan melaporkan pajaknya.
\end{abstract}

Kata kunci: Insentif, sosialisasi, UMKM

\section{PENDAHULUAN}

Penerimaan pajak adalah salah satu sumber APBN yang harus dikelola semaksimal mungkin dimana kondisi perekonomian pasca covid-19 saat ini yang masih belum menentu. Hal ini dilakukan untuk menjaga kestabilan suatu negara dalam memenuhi kebutuhan pembangunan daerah. Pada umumnya di negara-negara berkembang tentang kepatuhan pajak dan pengumpulan pajak masih menjadi masalah sampai saat ini (Freeman, 2008). Peran pajak di Indonesia saat ini dalam mensejahterakan masyarakat untuk menunjang kebutuhan masyarakat diberikan dalam bentuk fasilitas publik seperti transportasi, pendidikan, pelayanan kesehatan, dan lainnya (Umami, 2018).

Audina (2020) mengatakan sektor yang mengalami pertumbuhan yang sangat cepat di Indonesia saat ini ialah UMKM. UMKM memiliki kontribusi pada Produk Dmomestik Bruto (PDB) dan penyerapan tenaga kerja dalam waktu kurang lebih dua tahun UMKM memberikan 
sumbangsih sebesar 60,3\% dan 60\% di tahun 2018 dan 2019. Penyerapan tenaga kerja dari UMKM di tahun 2016 mencapai 97\%. Suatu hal yang wajib untuk dilaksanakan oleh perbankan ialah mendukung pengalokasian kredit atau pembiayaan kepada UMKM. Pada zaman globalisasi seperti sekarang ini, semua orang berkompetisi dalam menjalankan usaha UMKM dan memanfaatkan peluang bisnis yang ada, maka aturan keuangan bisnis yang menunjang sangat diperlukan UMKM (Kitadigi.com, 2020).

Dikutip dari Investor.id.com (2020) bahwa platform digital mengalami peningkatan yang drastis dan berperan dalam memberikan peluang bagi UMKM untuk maju dan bersinergi. Hal ini didukung oleh pemerintah dengan upaya gerakan UMKM Go-Online untuk menjadikan Indonesia sebagai Digital Energy of Asia. Pada tahun lalu, serangan wabah covid-19 menimpa dunia termasuk Indonesia memberikan dampak yang besar dalam pertumbuhan bisnis UMKM. Digitalisasi merupakan salah satu solusi bagi UMKM untuk dapat mengembangkan bisnisnya saat ini, dimana tidak sedikit yang mengalami kesulitan dan merugi bahkan sampai harus gulung tikar dan merumahkan karyawan dikarenakan perputaran modal biaya produksi yang tidak tercukupi. (Marlinah, 2020; Audina, 2020).

Terlepas dari isu nasional, Jawa Barat sebagai provinsi yang terdampak akibat pandemic covid-19 ini berupaya untuk menggerakkan sektor UMKM melalui digitalisasi usaha. Ridwan Kamil mengatakan bahwa sekitar 37 ribu pelaku UMKM di Jawa Barat terkena dampak Covid-19. Pada era Adaptasi Kebiasaan Baru ini Pemprov jabar mengatakan sekitar 17\% UMKM sudah melek digital dan berupaya agar tetap Tangguh dengan menumbuhkan keinginan daya beli masyarkat dan mendorong peningkatan omset usaha agar pertumbuhan ekonomi tetap positif (Jabarprov.go.id, 2020). Disdagkoperindag kota Cimahi yang merupakan bagian dari provinsi Jawa Barat mencatat sampai pada bulan juli 2020 terdapat 4.033 UMKM yang sudah terdaftar. Pertumbuhan tingakat ekonomi dan penyerapan tenaga kerja merupakan bagian dari peran UMKM dalam menggerakkan sektor ekonomi di berbagai lapangan usaha (Galamedia.com, 2020).

Perkembangan UMKM melalui digitalisasi usaha menjadi dasar kegiatan pengabdian masyarakat ini dilakukan. UMKM di Indonesia mempunyai potensi usaha yang besar namun masih belum diimbangin dengan tingkat kepedulian terhadap peran pencatatan dan pembukuan dalam membangun usaha tersebut. Pencatatan yang dilakukan UMKM masih hanya mencatat jumlah pengeluaran dan pemasukan keuangan secara sederhana. Hal tersebut belum bisa dijadikan sumber informasi yang tepat dan akurat dalam pengambilan keputusan terkait operasionalisasi usaha tersebut. Maka pelaku UMKM dituntut untuk mampu melampirkan pembukuan yang baik dengan tujuan kesesuaian dalam hal pelaporan pajak (Muljanto, 2020).

Endrianto (2015) menjelaskan bahwa penerimaan pajak saat ini masih di dominasi oleh wajib pajak besar yang jumlahnya kurang dari 1\%. Hal ini disebabkan oleh fokus Direktorat Jenderal Pajak masih mengutamakan wajib pajak besar namun pengawasan pada pelaku UMKM belum maksimal dilakukan dan kepatuhan pajak UMKM masih rendah. Maka berdasarkan hal ini, pengenalan dan pemahaman akan ketentuan perpajakan PPh bagi UMKM dan insentif apa saja yang diberikan pemerintah dalam membantu pemulihan ekonomi dalam menghadapi covid-19 oleh UMKM sangatlah penting, mengingat UMKM memiliki kontribusi terhadap penerimaan negara berupa pajak final yang dibayarkan. Dirjen Pajak memberikan kebijakan baik berupa aturan maupun insentif dalam mengatasi hal tersebut. Pemerintah memberikan insentif kepada pelaku UMKM dengan menurunkan tarif PPh Final menjadi 0,5\% dari sebelumnya 1\% dari total omzet atau penghasilan bruto yang tertuang pada PP No 23 Tahun 2018 (Hamzah dkk, 2020).

Berdasarkan hukum perpajakan UU No. 36 Tahun 2008 tentang Pajak Penghasilan dan UU No. 20 Tahun 2008 tentang Usaha Mikro, Kecil, dan Menengah menyebutkan kewajiban perpajakan bagi UMKM secara umum ialah mendaftarkan diri sebagai wajib pajak untuk mendapatkan NPWP atau dikukuhkan sebagai PKP, dan pemungutan, penyetoran dan pelaporan PPN apabila sudah menjadi PKP, dan menyetorkan dan melaporkan PPh baik dari pemotongan atau pemungutan yang dilakukan maupun atas $\mathrm{PPh}$ maupun pajak lainnya. Wajib pajak dikatakan patuh dalam perpajakan apabila memiliki pembukuan yang tertata dan terstruktur dan secara 
penuh mengetahui kewajiban pajak bagi UMKM. kurangnya pemahaman tentang peraturan perpajakan di Indonesia merupakan hal yang harus diperhatikan pemerintah dikarenakan masih kurangnya sosialisasi dan pemahaman tentang perpajakan dan kesadaran wajib pajak.

Masalah dalam kegiatan pengabdian masyarakat ini bahwa keadaan saat ini pasca covid19 menunjukkan bahwa banyak UMKM yang terdampak akibat keadaan pendemi yang hampir 2 tahun melanda perekonomian ini masih terdapat UMKM khususnya yang berada di kota Cimahi kurang mengetahui apa peranan UMKM dalam perpajakan, masih rendahnya pengetahuan pajak bagi UMKM dan masih banyak yang belum mengetahui dan memanfaatkan insentif apa saja yang diberikan pemerintah bagi UMKM terdampak covid-19 serta bagaimana cara menggunakan insentif yang ditanggung oleh pemerintah. Berdasarkan permasalahan tersebut maka dibutuhkan kegiatan pengabdian masyarakat berupa sosialisasi berupa peran pajak bagi umkm dan perpanjangan insentif pajak bagi yang terdampak pandemi. Kegiatan ini bermaksud untuk memberikan informasi dan arahan bagi pelaku UMKM dalam hal kewajiban sebagai wajib pajak dan insentif bagi yang terdampak. Tujuan yang diharapkan dari pengabdian masyarakat ini ialah UMKM mampu memahami tentang dasar dan peraturan perpajakan pada UMKM, pelaku usaha UMKM mampu memenuhi kewajiban perpajakan dan mengetahui serta menggunakan insentif yang saat ini untuk dapat menjalankan kewajiban perpajakan pasca pandemi covid-19.

Pratiwi dkk (2021) dalam kegiatan pengabdian masyarakat yang telah dilakukan dengan cara memberikan edukasi dan pendampingan bagi UMKM di kota Tarakan dengan menggunakan metode dengan beberapa tahap seperti observasi dan wawancara, penyuluhan dan bimbingan teknis, pemantauan dan evaluasi memberikan hasil yang siginifikan pada pemilik UMKM Rajut Jani dengan kegiatan tersebut sangat membantu dalam memberikan pemahaman tentang perpajakan UMKM. Hal ini juga sesuai dengan kegiatan pengabdian masyarakat yang telah dilakukan oleh Hamzah dkk (2020) dengan pemberian sosialisasi mengenai edukasi perpajakan yang telah diberikan kepada UMKM Songket Mayang di Palembang menyadari bahwa kewajiban perpajakan atas usaha yang dijalani dan memahami cara penyetoran, penghitungan dan pelaporan perpajakannya.

\section{METODE}

Pelaksanaan kegiatan ini dilakukan dalam bentuk metode sosialisasi dengan menggunakan pendekatan ceramah dan diskusi. Kegiatan ini dilakukan pada hari Jumat 13 Agustus 2021. Awal dari kegiatan dengan melakukan analisis situasi untuk mengumpulkan data melalui pemetaan masalah dan keselarasan tujuan antara pemkot cimahi dengan FEB Universitas Jenderal Achmad Yani. Pelaksanaan kegiatan ini dilakukan secara daring dengan mempertimbangkan masa pandemi yang masih belum menentu ini. Sosialiasasi terdiri dari tim pelaksana dari unsur dosen dan mahasiswa. Kegiatan diawali dengan menyiapkan instrument pendukung seperti zoom, narasumber, susunan acara dan penyamaan persepsi materi dengan narasumber untuk mendukung kelancaran sosialisasi dan diskusi. Laporan pelaksanaan kegaiatan adalah bentuk pertanggungjawaban akhir atas kegiatan ini.

Peserta pada kegiatan sosialisasi ini mencapai 70 orang yang diantaranya dosen prodi akuntansi, mahasiswa dan pelaku UMKM. Kegiatan ini mengangkat tiga konsep utama yaitu: Pengertian pajak atas UMKM, insentif perpajakan bagi UMKM terdampak Covid-19 dan tutorial cara memanfaatkan insentif pajak tersebut. Kegiatan ini dilakukan secara formal dengan susunana acara yaitu pemaparan materi, sesi tanya jawab dan diskusi, lalu pemberian doorprize pada akhir kegiatan sebagai penutup. Tahapan pelaksanaan dalam penyampaian materi pada webinar dalam kegiatan ini dilakukan dengan 4 tahap. Tahap pertama yaitu menjelaskan mengenai pajak bagi pelaku usaha skala UMKM sesuai dengan PP No 23 tahun 2018. Tahap kedua yaitu memberikan contoh kasus sampai proses penyetoran. Tahap ketiga yaitu insentif pajak berdasarkan PMK-82/PMK.03/2021 dimana yang berlaku sebelumnya PMK-9/PMK.03/2021 mengenai insentif bagi yang terdampak pandemi covid-19. dan terakhir menjelaskan tutorial cara memanfaatkan insentif pajak bagi UMKM serta diskusi tanya jawab. 
Sosialisasi ini dapat diukur dengan indikator pemahaman wajib pajak mengenai aturan pajak, pengetahuan peran UMKM dalam membayar pajak dan pemahaman dan pengetahuan UMKM dalam mengetahui fungsi dari insentif yang diberikan oleh pemerintah dengan tingkat ketercapaian yang diharapkan bahwa UMKM mampu memahami, membuat, menghitung dan melaporkan serta terampil dalam pemenuhan kewajiban perpajakannya.

\section{HASIL DAN PEMBAHASAN}

Hasil dari kegiatan yang telah dilakukan dengan pemaparan materi oleh narasumber yang kompeten pada bidangnya secara langsung kepada mitra dalam bentuk webinar. Kegiatan diawali dengan penyebaran flyer kepada mitra melalui WhatsApp yang telah dibentuk sebagai wadah untuk sharing session kepada mitra yaitu UMKM. Adapun flyer dan Grup yang dibuat sebagai berikut:

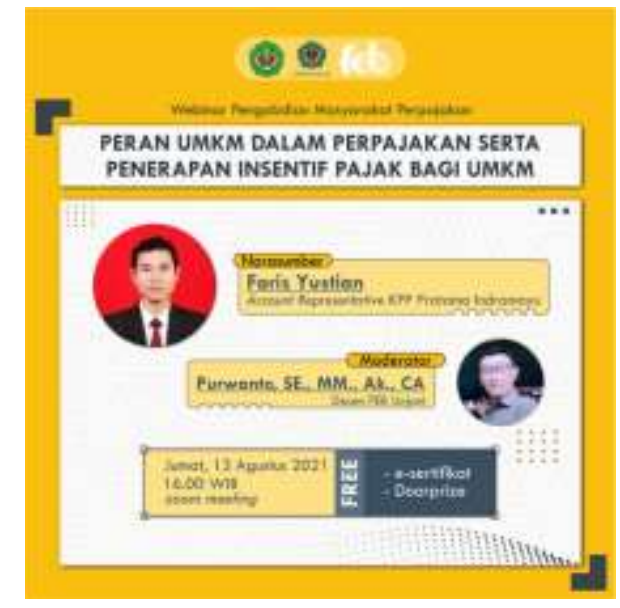

Gambar 1. Flyer Kegiatan Webinar

Narasumber yang kami undang untuk mengisi acara tersebut yaitu Bapak Faris Yustian yang memiliki background sebagai Account Representative pada KPP Pratam Indramayu dari tahun 2017 sampai dengan sekarang. Pemateri juga aktif sebagai pengajar brevet, dosen, tim kreatif DJP dan tim materi penyuluhan DJP. melihat latar belakang yang dimiliki ini sangatlah sesuai dengan kegiatan yang dilakukan dalam memberikan sosialiasasi pada UMKM mengenai perpajakan. Webinar ini dipandu oleh moderator yang memiliki keahlian dibidang perpajakan dengan background akademisi pada prodi akuntansi FEB di universitas Jenderal Achmad Yani. Rencana kegiatan dan tata tertib pelaksanaan diinformasikan kepada mitra melalui grup WhatsApp yang telah dibentuk sebelumnya untuk memudahkan dalam memberikan informasi. Adapun grup yang dibentuk sebagai berikut:

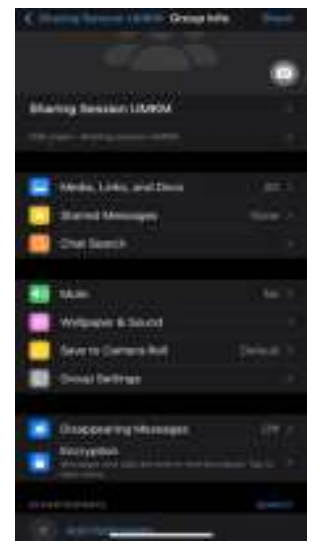

Gambar 2. WhatsApp Grup UMKM 
UMKM dapat melakukan komunikasi melalui grup yang dibentuk sesuai dengan gambar 2 tersebut. Harapannya dengan adanya komunikasi Bersama seperti ini dapat mempermudah mitra dalam berkoordinasi dan berdiskusi dalam hal apapun. Persiapan lain yang dilakukan dalam melakukan kegiatan ini dengan merancang e-sertifikat yang akan diberikan kepada mitra sebagai bukti bahwa pelaksanaan kegiatan pengabdian masyarakat ini telah diikuti dan dilaksanakan dengan semestinya. adapun rancangan sertifikat yang diberikan sebagai berikut:

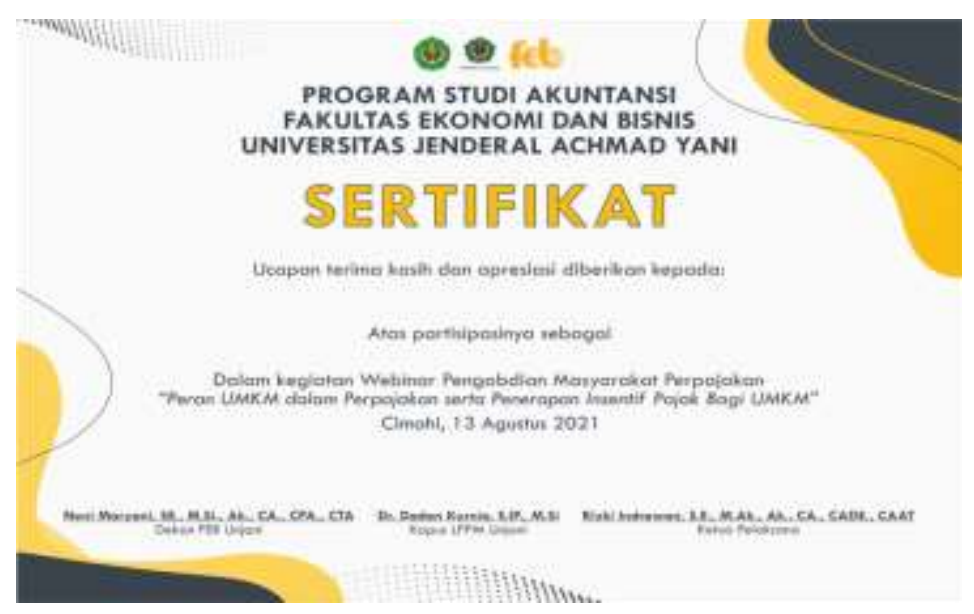

Gambar 3. Rancangan Sertifikat Kegiatan

Pada gambar 3 memperlihatkan bentuk dari sertifikat yang akan diberikan kepada mitra UMKM sebagai bukti bahwa mereka telah mengikuti kegiatan sampai dengan selesai. Pada sertifikat yang diberikan ini disetujui oleh Dekan FEB Unjani sebagai pelaksana utama kegiatan ini, dilanjutkan oleh kepala pusat Lembaga penelitian dan pengabdian masyarakat (LPPM) Unjani dan Ketua pelaksana kegiatan pengabdian ini. Hal ini berguna bagi masyarakat bahwa kegiatan ini didukung dan difasilitasi oleh Lembaga secara legal. Sehingga peserta merasa aman dan nyaman dalam mengikuti kegiatan tersebut. Selanjutnya kegiatan dilakukan menggunakan platform zoom sebagai wadah untuk melangsungkan acara webinar ini. Dibutuhkan penggunaan virtual background saat acara yang berguna untuk menyamakan latar belakang pada saat kegiatan. berikut bentuk viartual background yang digunakan.

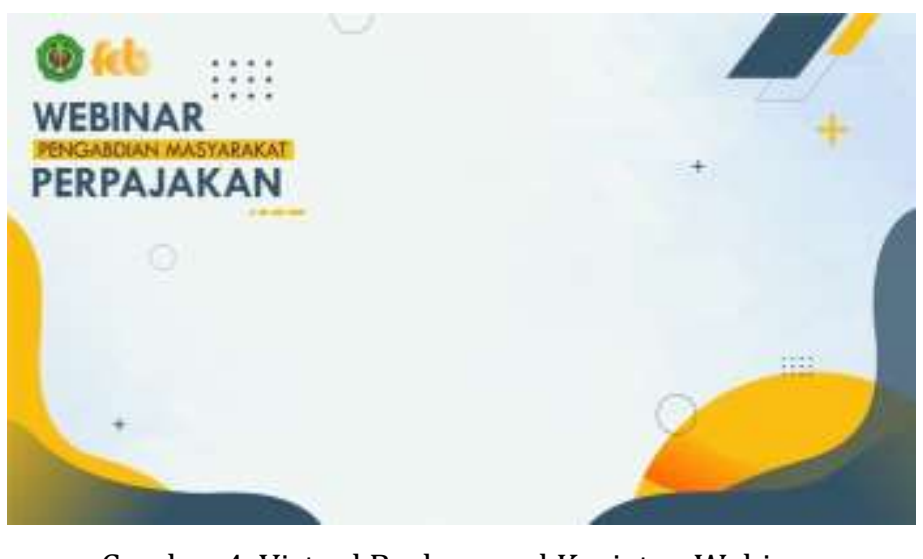

Gambar 4. Virtual Background Kegiatan Webinar

Gambar 4 digunakan untuk meminimalisir gangguan gambar saat video hidup saat acara berlangsung, dimana kegiatan dilakukan secara tatap muka agar seragam dan menarik saat berdiskusi. Rangkaian susunan acara dari kegiatan ini dapat dilihat sebagai berikut: 


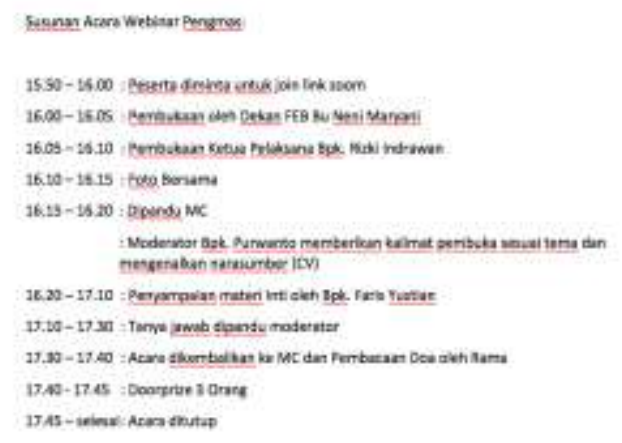

Gambar 5. Susunan Acara Kegiatan Webinar

Kegiatan dimulai dengan pembukaan yang disampaikan oleh ketua pelaksana webinar yang menyampaikan bahwa ini merupakan kegiatan rutin yang biasanya dilakukan satu tahun sekali secara offline, namun keadaan pandemi covid-19 ini mengharuskan penyelenggaraan dilakukan secara online. semoga bagaimanapun teknis pelaksanaannya, materi dapat diterima dengan baik dan bermanfaat bagi mitra pada khususnya dan bagi semua peserta pada umumnya. Kemudian dilanjutkan dengan penyampaian sambutan dari Dekan FEB Unjani yang mengatakan semoga kegiatan webinar ini membawa manfaat yang besar bagi peserta yang hadir.

Tahap selanjutnya ialah pemaparan materi yang disampaikan narasumber yang dipandu oleh moderator menyampaikan bahwa subjek dari pajak UMKM ialah orang pribadi dan badan usaha dan objek pajak UMKM berasal dari penghasilan usaha, memiliki peredaran bruto setahun kurang dari 4,8 Miliar yang merupakan total dari seluruh outlet yang dimiliki. Adapun cara menghitung $\mathrm{PPh}$ bagi UMKM sesuai $\mathrm{PP} / 23 / 2018$ berdasar pada penghasilan bruto dikalikan dengan tarif $0,5 \%$ dan bersifat final. Adapun gambar saat kegiatan webinar berlangsung sebagai berikut:

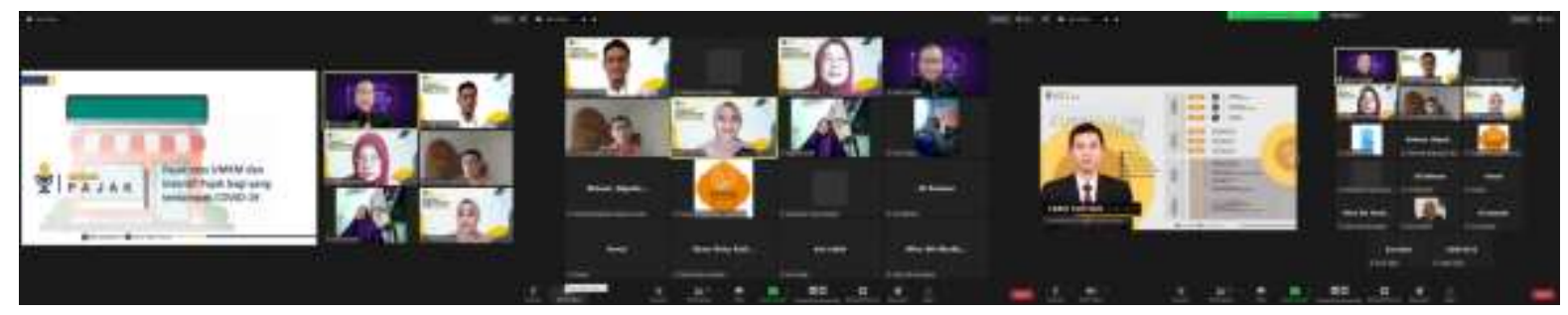

Gambar 6. Proses Sosialiasasi Berlangsung

Penyampaian materi diakhiri dengan sesi tanya jawab dengan para peserta yaitu pelaku UMKM melalui mekanisme menuliskan pertanyaan pada kolom chat yang ada pada platform zoom tersebut dan akan dibacakan oleh moderator atas pertanyaannya. Moderator juga melakukan resume terhadap setiap jawaban atas pertanyaan untuk mempermudah penyampaian kepada peserta. Terdapat batasan dalam memberikan pertanyaan yakni hanya 5 pertanyaan mengingat adanya keterbatasan waktu. Moderator menggaris bawahi 3 hal dari pemaparan materi yang telah disampaikan oleh narasumber, pertama subjek dan objek pajak UMKM, yang kedua insentif pajak UMKM yang sudah diberlakukan dan yang diperpanjang sampai akhir 2021 dengan harapan tidak diperpanjang lagi pada tahun selanjutnya yang artinya pandemi telah berakhir dan terakhir proses pelaporan insentif dilakukan secara online.

Pertanyaan pertama yang diajukan berkenaan dengan pelaku UMKM selama masa pandemi di tahun 2020 tidak melaksanakan kegiatan usaha sehingga berakibat pada pelaporan pajak nihil, apakah sudah sesuai atau diperlukan adanya perbaikan dan pada kegiatan usaha 2021 ini apakah bisa menggunakan insentif tersebut. Pemateri menanggapi pertanyaan ini dengan memberikan penjelasan bahwa yang sudah pelaku UMKM untuk tahun 2020 sudah benar dan wajib melaporkan SPT Tahunan baik ada atau tidak ada kegiatan usaha, baik kecil maupun besar, 
baik swasta maupun pegawa negeri sipil wajib lapor dikarenakan wajib pajak sudah memiliki NPWP yang sudah menjadi kewajiban sebagai wajib pajak. Kemudian pada tahun 2021 dipersilahkan menggunakan segara fasilitas insentif yang diberikan oleh pemerintah dalam bentuk Pph Final Ditanggung Pemerintah (DTP) untuk masa lapor bulan juli. Pertanyaan kedua membahas mengenai berapa nilai omzet yang kena wajib pajak untuk UMKM. narasumber menjawab berdasarkan aturan tidak ada batas bawah namun yang ada batas atas. sepanjang omzet masih dibawah 4,8 Miliar masih masuk kategori UMKM dan tidak ada batas bawah, sehingga apabila tidak ada kegiatan usaha maka kembali pada matematika dasar dengan mengkalikan tarif yang berlaku dengan omzet yang artinya berapapun penjualan sepanjang memiliki omzet maka sejumlah itu pajak yang dibayarkan.

Pertanyaan ketiga yang disampaikan mengenai apakah bisa dipandu untuk pajak UMKM. Bpk Faris menjawab bahwa bisa dengan cara melihat tutorial yang ada di youtube, kemudian bisa dengan datang langsung ke KPP bagian penyuluh pajak yang memiliki tugas untuk memberikan edukasi dan memandu bagaimana menghitung, menyetor dan melaporkan pajak dan bisa juga melalui sosial media KPP serta juga bisa menggunakan konsultan pajak namun membutuhkan biaya jika menggunakan jasa tersebut. Namun disarankan tips untuk bisa belajar pajak harus dilakukan dengan sendiri melalui media yang tersedia baik online maupun offline. Pajak itu dinamis dan terus akan mengalami perubahan seperti tarif PPh Final UMKM yang menjadi 0,5\% dari sebelumnya $1 \%$. Kemudian pertanyaan selanjutnya apakah e-fin dan e-billing merupakan hal yang sama. Menanggapi pertanyaan ini pemateri menjelaskan bahwa $e$-fin dan $e$-billing suatu hal yang berbeda. e-fin merupakan wadah dalam melakukan pelaporan secara online dan e-billing adalah perangkat pendukung untuk melakukan pembayaran pajak guna untuk pelaporan pajak.

Selama kegiatan berlangsung, peserta secara aktif ikut serta dan bersedia untuk dievaluasi dengan memberikan kuesioner feedback atas kegiatan tersebut yang diisi oleh peserta kegiatan menyampaikan bahwa 60\% mampu memahami atas materi yang telah disampaikan dan 39\% mengatakan mampu menerapkan apa yang telah dipelajari dalam menjalankan usahanya.
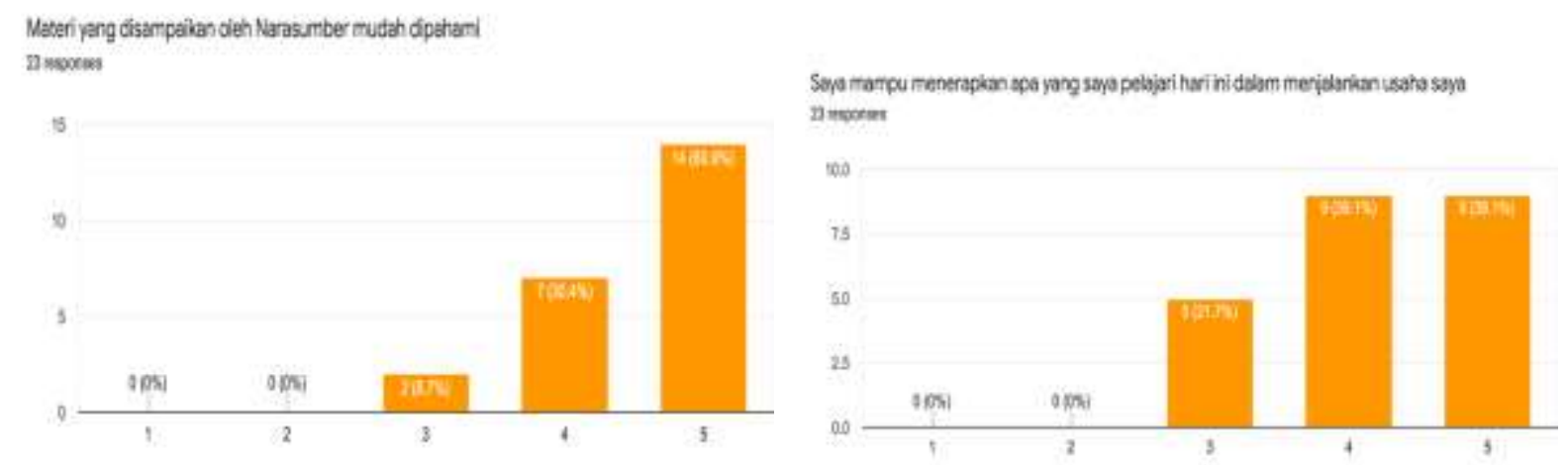

Gambar 7. Respon Peserta Kegiatan

Antusiasme peserta juga terlihat pada komentar yang diberikan atas kegiatan webinar ini. Komentar ini menjadi jawaban bagi kami sebagai panitia pelaksana merasakan kegiatan sosialisasi ini mampu memberikan pengetahuan, pemahaman dan terampil dalam memenuhi perpajakannya. 

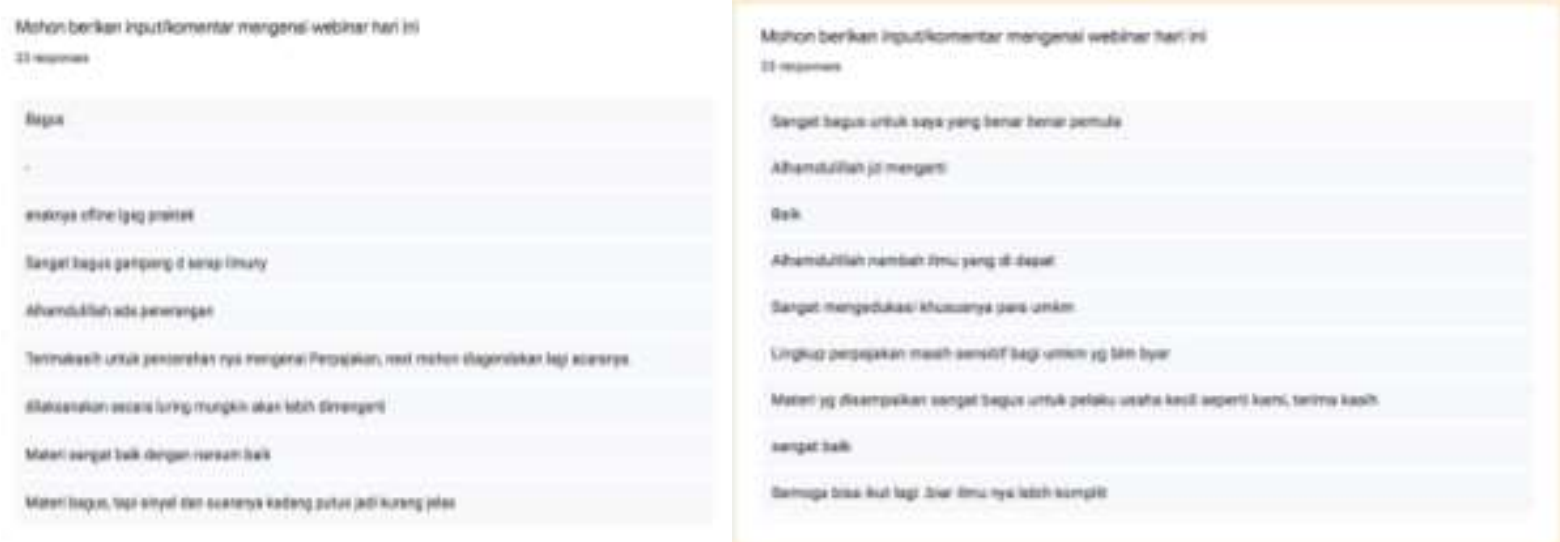

Gambar 8. Komentar Peserta atas Kegiatan

Kegiatan sosialisasi perpajakan ini ditutup dengan pemberian doorprize kepada peserta yang telah mengajukan pertanyaan melalui mekanisme undian. Undian dilakukan dengan menggunakan aplikasi wheelofnames.com dan kepuasan peserta atas kegiatan webinar ini. Kemudian pemberian sertifikat bagi peserta dan narasumber. Adapun salah satu bukti kegiatan terlihat pada gambar 9 dan gambar 10.
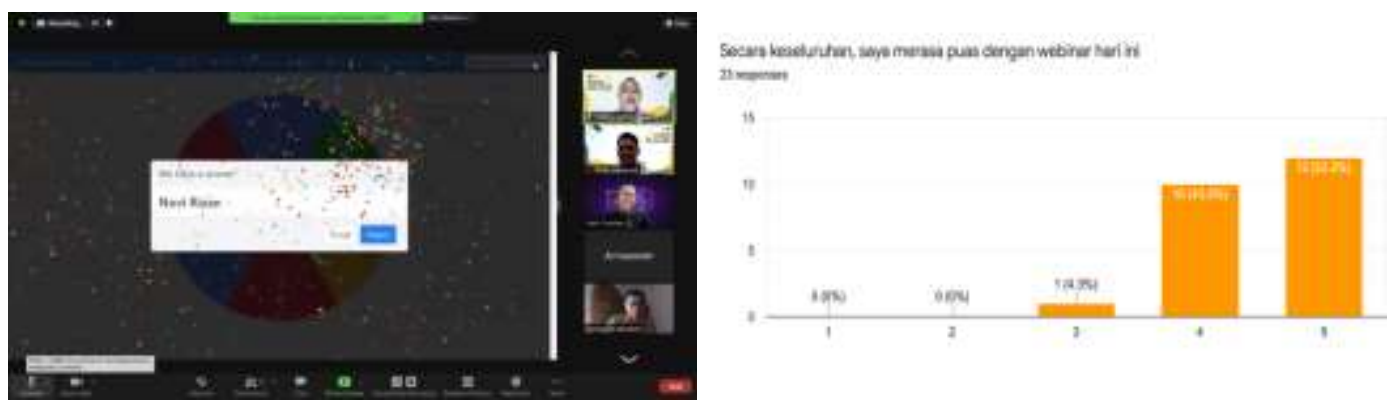

Gambar 9. Pemenang Doorprize \& Kepuasan Peserta
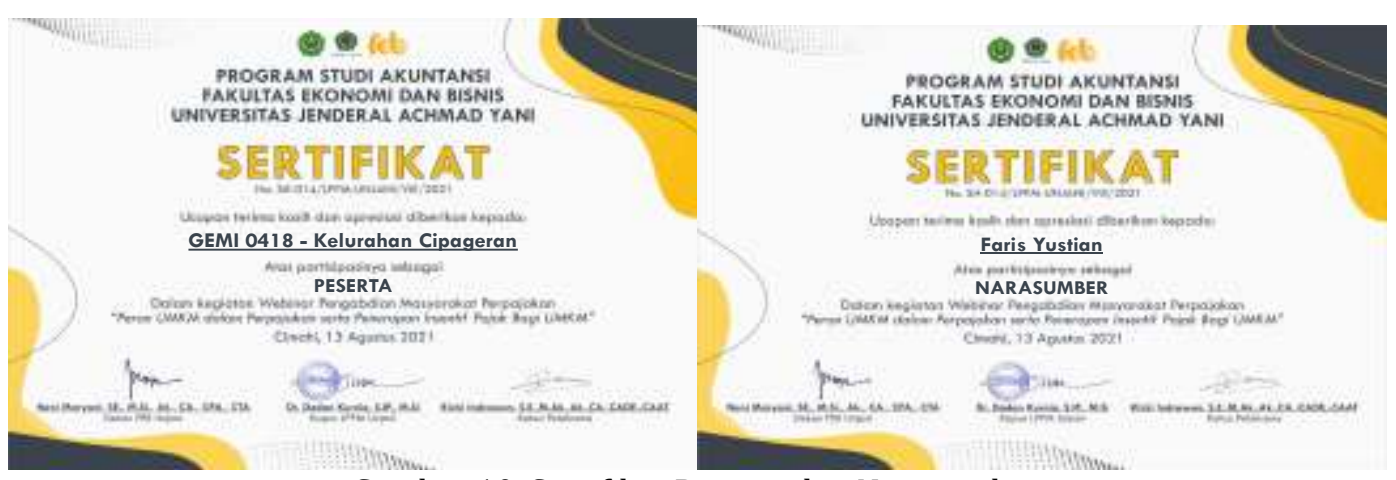

Gambar 10. Sertifikat Peserta dan Narasumber

Hasil kegiatan ini juga dipublikasi oleh media berita lokal dalam bentuk artikel yaitu tribunnews. Dengan hal ini mampu dijadikan referensi bagi pelaku usaha UMKM atau pembaca lainnya bahwa kegiatan ini telah berlangsung dan dapat dibaca kembali pada artikel tersebut. Selain itu kegiatan ini diposting juga pada media sosial seperti Instagram. 


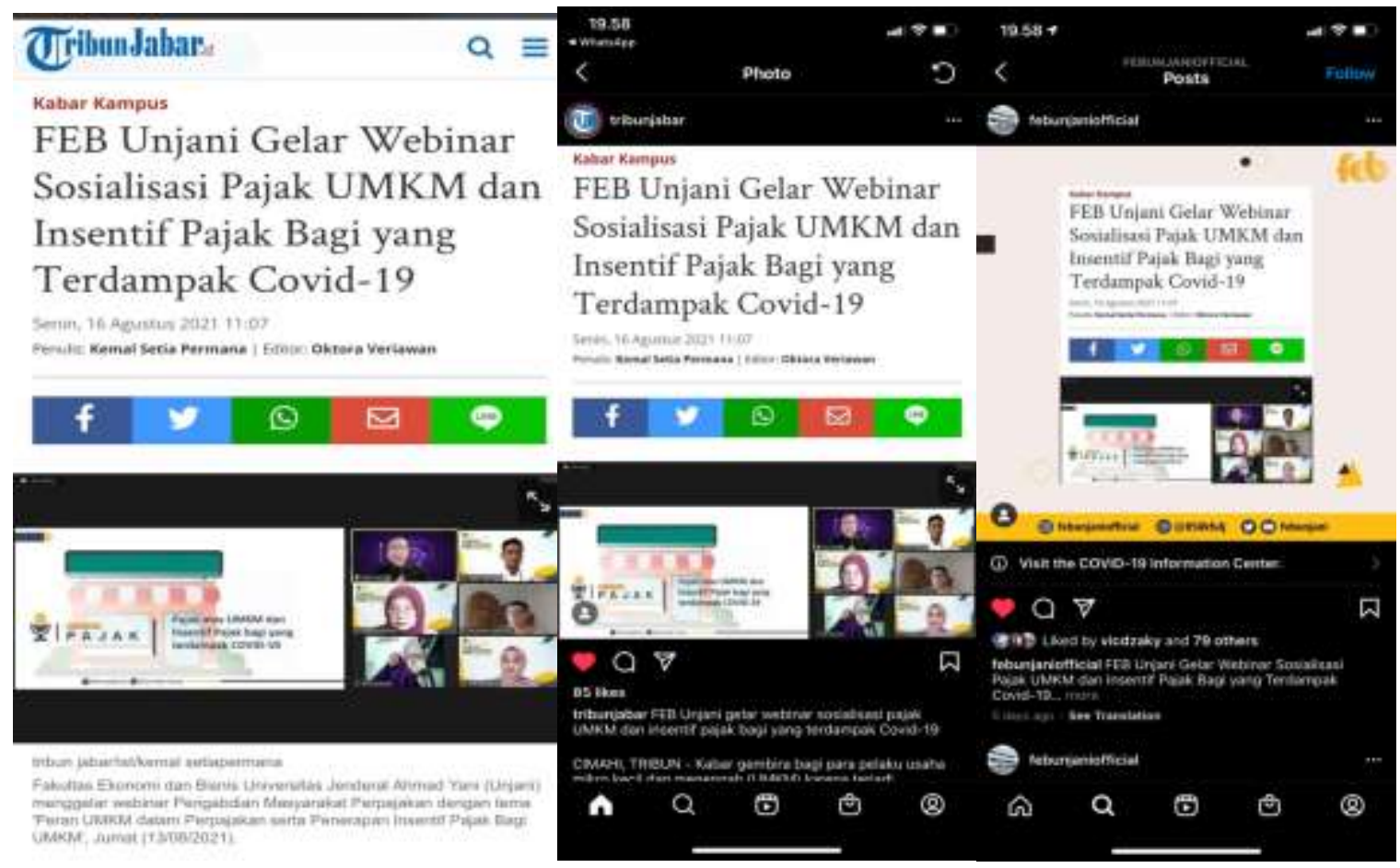

Gambar 11 Output Publikasi Kegiatan

\section{KESIMPULAN}

Berdasarkan webinar yang telah dilakukan dan evaluasi kegiatan menunjukkan bahwa kegiatan telah dilaksanakan dengan cukup baik ditunjukkan dengan keinginan yang dapat diimplementasikan pada usaha hampir mencapai $40 \%$ dan merasa puas dengan kegiatan ini mencapai 50\%. Masih belum mencapai sesuai dengan yang diinginkan, artinya kegiatan seperti ini perlu dilaksanakan secara periodik. Namun dengan adanya kegiatan ini pelaku UMKM memahami pentingnya memenuhi kewajiban pajak sebagai warga negara yang patuh. Berkenaan dengan hal ini, kegiatan pembelajaran pajak dapat dilakukan secara berkala dan menyasar kelompok usaha yang lebih besar lagi bentuk upaya peningkatan kesadaran pajak bagi pelaku usaha. adapun point utama yang ditarik menjadi suatu kesimpulan:

1. Sosialisasi perpajakan mengenai peran UMKM dalam perpajakan serta penerapan insentif pajak bagi UMKM di Kota Cimahi sebagai salah satu bentuk kegiatan pengabdian masyarakat tahun 2021 terselenggara dengan baik walaupun dilakukan secara daring. Pelaksanaan kegiatan yang dimulai dari penulisan proposal, perencanaan kegiatan dilapangan, pelaksanaan kegiatan sebagai inti dari kegiatan pengabdian masyarakat dan pelaporan kegiatan berjalan sesuai dan konsisten dengan jadwal yang telah ditentukan.

2. Inti materi yang disampaikan terdiri dari 3 konsep utama yaitu Pengertian Pajak, Insentif pajak bagi yang terdampak dan tutorial penggunaan fasilitas insentif PPh Final DTP yang diberikan oleh pemerintah telah disampaikan keseluruhan kepada peserta kegiatan. Respon yang diberikan oleh peserta juga sangat baik pada kegiatan berlangsung. kondisi ini diharapkan dapat menambah pemahaman pelaku UMKM dalam upaya mencapai UMKM di kota Cimahi patuh pajak. 


\section{UCAPAN TERIMA KASIH}

Ucapan terima kasih penulis sampaikan kepada seluruh panitia kegiatan dan FEB Universitas Jenderal Achmad Yani serta kepada LPPM Universitas Jenderal Achmad Yani yang telah memberikan dukungan financial terdahap pengabdian ini.

\section{DAFTAR PUSTAKA}

Freeman RE (2008). Managing for stakeholders. In: T. Donaldson, P. Werhane (Eds.), Ethical Issues in Business: A Philosophical approach, 8th Edition. Prentice Hall, Englewood Cliffs, NJ, pp. 3953.

Fitria, P. N., \& Supriyono, E. (2019). Pengaruh pemahaman peraturan perpajakan, persepsi tarif pajak, dan keadilan perpajakan terhadap kepatuhan wajib pajak. Ecobank: Journal of Economics and Banking, 1 (1), 47-54.

Hamzah, R.S., Sri, M., Trie, S.P., \& Nur, K. (2020). Edukasi dan Pendampingan Pelaksanaan Perhitungan Pajak di UMKM Kerajinan Songket Mayang Palembang. Jurnal Abdimas Mandiri Vol. 4 No. 2. November. pp. 95-102. E-ISSN :2598-425X, P-ISSN :2598-241.

Mustofa, F.A, Kertahadi, \& R Maulinarhadi, M. (2016). Pengaruh Pemahaman Peraturan Perpajakan, Tarif Pajak dan Asas Keadilan terhadap Kepatuhan Wajib Pajak (Studi Pada Wajib Pajak Usaha Mikro, Kecil dan Menengah yang Berada di Wilayah Kerja Kantor Pelayanan Pajak Pratama Batu Setelah Diberlakukannya Peraturan Pemerintah No 46 Tahun 2013. Jurnal Perpajakan (JEJAK). Vol. 8 No. 1. perpajakan.studentjournal.ub.ac.id.

Umami Riza (2018). Pengaruh Penerapan E-Filling, Tingkat Pemahaman Dan Kesadaran Wajib Pajak Terhadap Kepatuhan Dalam Melaporkan SPT dI KP2KP Lumajang), E-ISSN :2622-304X, P-ISSN : 2622-3031, Lumajang.

UU No. 6 Tahun 1983 sebagaimana telah diubah terakhir dengan UU No. 16 Tahun 2009 Tentang Ketentuan Umum Perpajakan.

UU No. 7 Tahun 1983 sebagaimana telah diubah terakhir dengan UU No. 36 Tahun 2008 Tentang Pajak Penghasilan.

UU No. 20/2008 Tentang Usaha Mikro, Kecil Dan Menengah. Kewajiban Perpajakan bagi UMKM

PMK-82/PMK.03/2021 Perubahan atas PMK-9/PMK.03/2021 tentang Insentif Pajak Untuk Wajib Pajak Terdampak Pandemi Covid-19.

PP 23 Tahun 2018 tentang PPh atas penghasilan dari usaha yang diterima atau diperoleh wajib pajak yang memiliki peredaran bruto tertentu

Pratiwi, S.R., Yohanna, T.N., Charitin, D., \& Meylin. R. (2021). Edukasi Perpajakan bagi UMKM di Kota Tarakan. Aplikasi Riset Kepada Masyarakat (ARSY) Vol. No 2 Hal 14-22.

Putri, T., Saerang, D. P. E., \& Budiarso, N. S. (2019). Analisis perilaku wajib pajak UMKM terhadap pelaksanaan pemungutan pajak dengan menggunakan self assessment system di Kota Tomohon. Jurnal Riset Akuntansi Going Concern, 14 (1), 130-136.

Sandra, A dkk. (2019). Pendampingan Pajak UMKM: Masalah dan Solusinya. Academics in Action Journal. Volume 1, Number 1, 2019, 1-7. 